\title{
Reclassification of Thermoterrabacterium ferrireducens as Carboxydothermus ferrireducens comb. nov., and emended description of the genus Carboxydothermus
}

\author{
Correspondence \\ A. I. Slobodkin \\ aslobodkin@hotmail.com
}

\author{
A. I. Slobodkin, ${ }^{1}$ T. G. Sokolova, ${ }^{1}$ A. M. Lysenko ${ }^{1}$ and J. Wiegel ${ }^{2}$ \\ ${ }^{1}$ Winogradsky Institute of Microbiology, Russian Academy of Sciences, Prospect 60-letiya \\ Oktyabrya 7/2, 117312 Moscow, Russia \\ ${ }^{2}$ Department of Microbiology, University of Georgia, Athens, GA 30602, USA
}

\begin{abstract}
Similarities in phylogeny and metabolic properties between the type species of two monospecific genera of thermophilic anaerobic bacteria, Carboxydothermus hydrogenoformans and Thermoterrabacterium ferrireducens, and analysis of their recently available 16S rRNA gene sequences warranted clarification of their taxonomic positions. We have determined that the value of DNA-DNA hybridization between the type strains is $53 \%$. Additional physiological studies revealed that $C$. hydrogenoformans $\mathrm{Z}-2901^{\top}$ is capable of $\mathrm{Fe}(\mathrm{III})$ reduction with $\mathrm{H}_{2}$ as an electron donor and ferrihydrite as an electron acceptor. T. ferrireducens JW/AS-Y $7^{\top}$ is able to grow and utilize $\mathrm{CO}$ with ferrihydrite as an electron acceptor without hydrogen or acetate production. We therefore reclassify Thermoterrabacterium ferrireducens as Carboxydothermus ferrireducens comb. nov. (type strain JW/AS-Y $7^{\top}=\mathrm{DSM} 11255^{\top}=\mathrm{VKM} \mathrm{B}-2392^{\top}$ ). The description of the genus Carboxydothermus is emended to include such important physiological properties as growth on organic compounds and capacity for $\mathrm{Fe}(\mathrm{III})$ reduction.
\end{abstract}

Thermoterrabacterium ferrireducens JW/AS- $\mathrm{Y}^{\mathrm{T}}$, a thermophilic, anaerobic, dissimilatory $\mathrm{Fe}(\mathrm{III})$-reducing bacterium, was isolated from a hot spring in Yellowstone National Park (Slobodkin et al., 1997). This micro-organism grew via utilization of organic substrates or molecular hydrogen and, besides ferric iron, reduced several other electron acceptors. 16S rRNA gene sequence analysis placed T. ferrireducens within the Bacillus-Clostridium subphylum, with the most closely related micro-organism at the time of description being Ammonifex degensii ( $83 \%$ similarity). The combination of physiological properties and phylogenetic position allowed the organism to be assigned to a new genus.

The genus Carboxydothermus contains a single species, Carboxydothermus hydrogenoformans, an anaerobic carbon monoxide-utilizing thermophilic bacterium (Svetlichny et al., 1991a). The name of this species was subsequently validly published (Svetlichny et al., 1991b). A partial 16S rRNA gene sequence of C. hydrogenoformans $\mathrm{Z}-2901^{\mathrm{T}}$ became available in 2000 (GenBank accession no. AF244579), and analysis revealed $98.4 \%$ similarity between this sequence and that of T. ferrireducens JW/AS$\mathrm{Y}^{\mathrm{T}}$ (GenBank accession no. U76363) (Sokolova et al., 2001). The phylogenetic position of C. hydrogenoformans is confirmed by recently published whole-genome sequence data (Wu et al., 2005; GenBank accession no. NC_007503).
This phylogenetic resemblance motivated Henstra \& Stams (2004) to investigate the physiological properties of both micro-organisms in more detail. They found that the growth substrates for C. hydrogenoformans are not restricted to $\mathrm{CO}$ and pyruvate, as was previously reported (Pusheva \& Sokolova, 1995), but that this bacterium is able to utilize various electron donors and acceptors for growth. The range of compounds utilized was identical to those used by $T$. ferrireducens. On the other hand, T. ferrireducens was capable of growth on $\mathrm{CO}$ with 9,10-anthraquinone 2,6disulfonate or fumarate as electron acceptors (Henstra \& Stams, 2004). Thus, the similarities in phylogeny and metabolic properties between C. hydrogenoformans and $T$. ferrireducens warranted a clarification of their taxonomic positions, as given below.

C. hydrogenoformans DSM $6008^{\mathrm{T}}\left(=\mathrm{Z}-2901^{\mathrm{T}}\right)$ and $T$. ferrireducens DSM $11255^{\mathrm{T}}\left(=\mathrm{JW} / \mathrm{AS}-\mathrm{Y}^{\mathrm{T}}\right)$ were obtained from the Deutsche Sammlung von Mikroorganismen und Zellkulturen $\mathrm{GmbH}$ (Braunschweig, Germany) and routinely cultivated at $65^{\circ} \mathrm{C}$ in mineral media as described previously (Svetlichny et al., 1991a; Slobodkin et al., 1997) with $100 \% \mathrm{CO}$ as the headspace gas (C. hydrogenoformans) and with the addition of glycerol $(30 \mathrm{mM})$ and fumarate $(20 \mathrm{mM})$ (T. ferrireducens). Growth of both micro-organisms in the presence of $\mathrm{Fe}(\mathrm{III})$ was investigated in anaerobic 
bicarbonate-buffered medium (Slobodkin et al., 1997) supplied with $0 \cdot 2$ g yeast extract $1^{-1}$ (Sigma). Ferrihydrite [poorly crystalline $\mathrm{Fe}(\mathrm{III})$ oxide] $(90 \mathrm{mM}), \mathrm{Fe}(\mathrm{III})$ citrate $(20 \mathrm{mM})$ or $\mathrm{Fe}(\mathrm{III})$ EDTA $(15 \mathrm{mM})$ was provided as an electron acceptor and CO (100\% as headspace gas), $\mathrm{H}_{2}$ (in the presence of $\mathrm{CO}_{2}$ at a ratio of $\left.80: 20\right)$, formate $(20 \mathrm{mM})$, lactate $(20 \mathrm{mM})$ or glycerol $(30 \mathrm{mM})$ was provided as an electron donor. In all experiments with different forms of $\mathrm{Fe}(\mathrm{III})$, the medium did not contain any reducing agents. Microscopy, cell counts and analysis of $\mathrm{CO}$, acetate and $\mathrm{Fe}(\mathrm{II})$ were carried out as described elsewhere (Slobodkin et al., 1997; Sokolova et al., 2001). The DNA was extracted and purified by the method of Marmur (1961). DNA-DNA hybridization studies were performed by the optical reassociation method as described previously (Krivenko et al., 1990).

The important physiological difference between C. hydrogenoformans and T. ferrireducens in $\mathrm{CO}$ metabolism is $\mathrm{H}_{2}$ production by $C$. hydrogenoformans irrespective of the cultivation conditions. T. ferrireducens does not produce molecular hydrogen during $\mathrm{CO}$ utilization and is unable to grow on CO without an external electron acceptor. Growth of C. hydrogenoformans with $\mathrm{Fe}(\mathrm{III})$ and the ability of $T$. ferrireducens to utilize $\mathrm{CO}$ with $\mathrm{Fe}(\mathrm{III})$ as an electron acceptor have not been investigated previously. Our attempts to obtain sustainable growth of $C$. hydrogenoformans with either CO, glycerol or lactate as an electron donor and either ferrihydrite, $\mathrm{Fe}(\mathrm{III})$ citrate or Fe(III) EDTA as an electron acceptor did not yield positive results. The only electron donor/acceptor couple that supported growth and $\mathrm{Fe}(\mathrm{III})$ reduction by this organism was $\mathrm{H}_{2} /$ ferrihydrite. Under these conditions, within 7 days of cultivation, the maximal cell yield was $3 \cdot 5-4 \cdot 0 \times 10^{7}$ cells ml $^{-1}$, ferrihydrite was converted to a black magnetic precipitate with a $\mathrm{Fe}$ (II) content of $20-22 \mathrm{mM}$ and no accumulation of acetate was found in the cultivation medium. Thus, the type species of the genus Carboxydothermus is capable of $\mathrm{Fe}(\mathrm{III})$ reduction. The inability of $C$. hydrogenoformans to grow on $\mathrm{CO}$ with $\mathrm{Fe}(\mathrm{III})$ is probably caused by the higher redox potential of the medium in comparison with the medium pre-reduced with $\mathrm{Na}_{2} \mathrm{~S} .9 \mathrm{H}_{2} \mathrm{O}$ used in previous studies (Svetlichny et al., 1991a; Henstra \& Stams, 2004). As evident from growth on $\mathrm{H}_{2}$ /ferrihydrite, the hydrogenase of $C$. hydrogenoformans can work at higher redox potential than CO dehydrogenase. In contrast to C. hydrogenoformans, T. ferrireducens grew and utilized $\mathrm{CO}$ with ferrihydrite as an electron acceptor. After 7 days of cultivation, the maximal cell yield was $2 \cdot 5-3 \cdot 0 \times 10^{7}$ cells ml $^{-1}$, ferrihydrite was converted to a black magnetic precipitate with a Fe(II) content of $26-28 \mathrm{mM}$ and $14 \mathrm{mM} \mathrm{CO}$ was consumed from the gas phase ( $45 \%$ of the initial concentration) without producing acetate.

Subsequently, DNA-DNA hybridization of T. ferrireducens DSM $11255^{\mathrm{T}}$ with C. hydrogenoformans DSM $6008^{\mathrm{T}}$ revealed a reassociation value of $53 \%$. This level of relatedness is characteristic of different species belonging to the same genus (Johnson, 1984).
Considering the physiological similarities, phylogenetic position and level of DNA-DNA relatedness, T. ferrireducens and C. hydrogenoformans should be members of the same genus. According to the Bacteriological Code (Lapage et al., 1992), the name Carboxydothermus has priority, thus T. ferrireducens has to be reclassified as a member of the genus Carboxydothermus. However, according to the original description (Svetlichny et al., 1991a), representatives of the genus Carboxydothermus utilize $\mathrm{CO}$ with equimolar formation of $\mathrm{H}_{2}$ and $\mathrm{CO}_{2}$, do not utilize other organic and inorganic substrates and do not reduce sulfur. Therefore, taking into account the data obtained by Henstra \& Stams (2004) and those generated in this study, the description of the genus Carboxydothermus needs to be emended.

\section{Emended description of the genus Carboxydothermus Svetlichny et al. 1991}

Rod-shaped, Gram-type positive (eu)bacteria. Anaerobic and thermophilic. Neutrophilic. Utilize CO either with or without production of molecular hydrogen. Able to couple the reduction of external electron acceptors such as Fe(III), sulfite, thiosulfate, elemental sulfur, nitrate, fumarate or 9,10-anthraquinone 2,6-disulfonate with oxidation of organic acids, polyols and $\mathrm{H}_{2}$. In the presence as well as in the absence of an electron acceptor, organic substrates are oxidized incompletely to acetate as the main metabolic product. Do not reduce sulfate.

\section{Description of Carboxydothermus ferrireducens comb. nov.}

Carboxydothermus ferrireducens [fer.ri.re.du'cens. L. n. ferrum iron; L. part. adj. reducens converting to a different state; N.L. part. adj. ferrireducens reducing (ferric) iron].

Basonym: Thermoterrabacterium ferrireducens Slobodkin et al. 1997.

The description is based on that published previously for Thermoterrabacterium ferrireducens (Slobodkin et al., 1997) with the additional data obtained by Gavrilov et al. (2003), Henstra \& Stams (2004) and during this study. Cells are straight to slightly curved rods, $0 \cdot 3-0 \cdot 4 \mu \mathrm{m}$ in diameter and $1 \cdot 6-2 \cdot 7 \mu \mathrm{m}$ in length with rounded ends. Cells stain Grampositive. Cells occur singly or in pairs, with retarded peritrichous flagellation, and exhibit tumbling motility. Spores are not observed. Anaerobic. Grows in mineral medium without supplementation with complex media components. The temperature range for growth is $50-74{ }^{\circ} \mathrm{C}$ with an optimum at $65^{\circ} \mathrm{C}$. The $\mathrm{pH}^{65^{\circ} \mathrm{C}}$ range for growth is $5 \cdot 5-7 \cdot 6$, with an optimum at $6 \cdot 0-6 \cdot 2$. No growth was observed at or below $48{ }^{\circ} \mathrm{C}$, at or above $76^{\circ} \mathrm{C}$, at or below $\mathrm{pH}^{65^{\circ} \mathrm{C}} 5 \cdot 3$ and at or above $\mathrm{pH}^{65^{\circ} \mathrm{C}} 7 \cdot 8$. Growth occurs at $\mathrm{NaCl}$ concentrations in the range of $0-1 \cdot 0 \%(\mathrm{w} / \mathrm{v})$. In the presence of $\mathrm{CO}_{2}$, the type strain is able to grow with glycerol as the only organic carbon source. Couples the oxidation of glycerol to reduction of ferrihydrite [poorly crystalline $\mathrm{Fe}(\mathrm{III})$ oxide], $\mathrm{Fe}$ (III) citrate or Fe(III) EDTA as electron 
acceptors. In the presence as well as in the absence of $\mathrm{Fe}(\mathrm{III})$ and in the presence of $\mathrm{CO}_{2}$, glycerol is oxidized incompletely to acetate as the only organic metabolic product, leading to a ratio of more than one acetate molecule produced per glycerol molecule consumed. Does not produce $\mathrm{H}_{2}$. Utilizes glycerol, lactate, 1,2-propanediol, glycerate, pyruvate, yeast extract and peptone. Grows weakly on glucose, fructose and mannose, producing acetate as the only organic product. In the presence of ferrihydrite, grows lithoautotrophically with molecular hydrogen as an electron donor and $\mathrm{CO}_{2}$ as the only carbon source. Utilizes $\mathrm{CO}$ with ferrihydrite, fumarate or 9,10-anthraquinone 2,6-disulfonate as electron acceptors, without the production of molecular hydrogen or acetate. No growth occurs with acetate, methanol, ethanol, 1propanol, 2-propanol, 1-butanol, propionate, acetone, ethylene glycol, 1,3-propanediol, fumarate, succinate, phenol, benzoate, 9,10-anthraquinone 2,6-disulfonate, starch, olive oil, elemental sulfur, sucrose, galactose, xylose, cellobiose or arabinose with or without $\mathrm{Fe}(\mathrm{III})$. Reduces $\mathrm{Fe}(\mathrm{III})$ to $\mathrm{Fe}(\mathrm{II}), 9,10$-anthraquinone 2,6-disulfonate to 9,10-anthrahydroquinone 2,6-disulfonate, fumarate to succinate, thiosulfate to elemental sulfur or sulfide, sulfite to sulfide, elemental sulfur to sulfide and nitrate to nitrite and ammonium. Does not reduce $\mathrm{MnO}_{2}$ or sulfate. Growth is inhibited by chloramphenicol, erythromycin and rifampicin at $100 \mu \mathrm{g} \mathrm{ml}^{-1}$ but not by $100 \mu \mathrm{g}$ ampicillin, streptomycin or tetracycline $\mathrm{ml}^{-1}$. The DNA base composition is $41 \mathrm{~mol} \% \mathrm{G}+\mathrm{C}$ (HPLC).

The type strain is JW/AS-Y7 $7^{\mathrm{T}}\left(=\mathrm{DSM} 11255^{\mathrm{T}}=\mathrm{VKM}\right.$ B$\left.2392^{\mathrm{T}}\right)$, isolated from a freshwater hot spring in the Calcite Springs area of Yellowstone National Park, WY, USA.

\section{Acknowledgements}

This work was supported by the programs 'Molecular and Cell Biology' and 'Origin and Evolution of Life' of the Russian Academy of Sciences and by grant 06-04-48684-a from the Russian Foundation for Basic Research.

\section{References}

Gavrilov, S. N., Bonch-Osmolovskaya, E. A. \& Slobodkin, A. I. (2003). Physiology of organotrophic and lithotrophic growth of the thermophilic iron-reducing bacteria Thermoterrabacterium ferrireducens and Thermoanaerobacter siderophilus. Microbiology (English translation of Mikrobiologiia) 72, 132-137.

Henstra, A. M. \& Stams, A. J. M. (2004). Novel physiological features of Carboxydothermus hydrogenoformans and Thermoterrabacterium ferrireducens. Appl Environ Microbiol 70, 7236-7240.

Johnson, J. L. (1984). Nucleic acids in bacterial classification. In Bergey's Manual of Systematic Bacteriology, vol. 1, pp. 8-11. Edited by N. R. Krieg \& J. G. Holt. Baltimore: Williams \& Wilkins.

Krivenko, V. V., Vadachkoriya, R. M., Chernykh, N. A., Mityushina, L. L. \& Krassilnikova, E. N. (1990). Clostridium uzonii sp. nov., an anaerobic thermophilic glycolytic bacterium from the hot springs of Kamchatka. Microbiology (English translation of Mikrobiologiia) 59, 741-749.

Lapage, S. P., Sneath, P. H. A., Lessel, E. F., Skerman, V. B. D., Seeliger, H. P. R. \& Clark, W. A. (editors) (1992). International Code of Nomenclature of Bacteria (1990 Revision). Bacteriological Code. Washington, DC: American Society for Microbiology.

Marmur, J. (1961). A procedure for the isolation of desoxyribonucleic acid from microorganisms. J Mol Biol 3, 208-218.

Pusheva, M. A. \& Sokolova, T. G. (1995). Distribution of COdehydrogenase activity in anaerobic thermophilic carboxydotrophic bacterium Carboxydothermus hydrogenoformans grown at the expense of $\mathrm{CO}$ or pyruvate. Microbiology (English translation of Mikrobiologiia) 64, 491-495.

Slobodkin, A. I., Reysenbach, A.-L., Strutz, N., Dreier, M. \& Wiegel, J. (1997). Thermoterrabacterium ferrireducens gen. nov., sp. nov. a thermophilic anaerobic, dissimilatory $\mathrm{Fe}(\mathrm{III})$-reducing bacterium from a continental hot spring. Int J Syst Bacteriol 47, 541-547.

Sokolova, T. G., Gonzalez, J. M., Kostrikina, N. A., Chernyh, N. A., Tourova, T. P., Kato, C., Bonch-Osmolovskaya, E. A. \& Robb, F. T. (2001). Carboxydobrachium pacificum gen. nov., sp. nov., a new anaerobic, thermophilic, CO-utilizing marine bacterium from Okinawa Trough. Int J Syst Evol Microbiol 51, 141-149.

Svetlichny, V. A., Sokolova, T. G., Gerhardt, M., Ringpfeil, M., Kostrikina, N. A. \& Zavarzin, G. A. (1991a). Carboxydothermus hydrogenoformans gen. nov., sp. nov., a CO-utilizing thermophilic anaerobic bacterium from hydrothermal environments of Kunashir Island. Syst Appl Microbiol 14, 245-260.

Svetlichny, V. A., Sokolova, T. G., Gerhardt, M., Ringpfeil, M., Kostrikina, N. A. \& Zavarzin, G. A. (1991b). Carboxydothermus hydrogenoformans gen. nov., sp. nov. In Validation of the Publication of New Names and New Combinations Previously Effectively Published Outside the IJSB, List no. 39. Int J Syst Bacteriol 41, 580-581.

Wu, M., Ren, Q., Durkin, A. S. \& 14 other authors (2005). Life in hot carbon monoxide: the complete genome sequence of Carboxydothermus hydrogenoformans Z-2901. PLoS Genet 1, e65. 